Article

\title{
Disinfection of Escherichia coli by a Reactive Electrochemical Membrane System Involving Activated Carbon Fiber Cloth (ACFC)
}

\author{
Edward Huang ${ }^{1}$, Townshend White ${ }^{2}$, Beibei Wang ${ }^{3}$, Huanhuan Shi ${ }^{3, *}$ and Jiayang Liu ${ }^{3,4, *}$ \\ 1 Whitewater High School, 100 Wildcat Way, Fayetteville, GA 30215, USA; edwardhuang02@gmail.com \\ 2 Brookwood High School, 1255 Dogwood Road SW, Snellville, GA 30078, USA; townshendwhite@gmail.com \\ 3 Department of Crop and Soil Sciences, University of Georgia, Griffin, GA 30223, USA; Beibei.Wang@uga.edu \\ 4 School of Bioengineering, Huanghuai University, Zhumadian 463000, China \\ * Correspondence: shihuanhuan222@uga.edu (H.S.); liujiayang5@163.com (J.L.); Tel.: +1-404-232-9787 (H.S.); \\ $+86-18839648638$ (J.L.)
}

Received: 29 January 2019; Accepted: 23 February 2019; Published: 28 February 2019

\begin{abstract}
This study examined a novel reactive electrochemical membrane (REM) system with activated carbon fiber cloth (ACFC) serving simultaneously as the anode and the membrane to effectively disinfect water that was filtered through the device. An Escherichia coli strain was inoculated to water as a model pathogen. The influence of REM operation parameters, including the number of ACFC layers, voltage, flow rate and operation time, was evaluated. Up to 7.5 log unit reduction of $E$. coli concentration in water was achieved at the optimal treatment condition, while the energy consumption was $1.5 \mathrm{kWh} / \mathrm{m}^{3}$ per log unit reduction of E. coli. This makes it possible to use this ACFC-based REM technology for point-of-use water disinfection to provide clean water for underdeveloped regions. Further tests by free radical probing, Linear Scan Voltammetry (LSV) and Scanning Electron Microscopy (SEM) suggest that the disinfection involved the filtration/retention of bacteria on ACFC and attack by reactive oxygen species generated electrochemically on the anode.
\end{abstract}

Keywords: electrochemical; activated carbon fiber cloth; disinfection; pathogen

\section{Introduction}

Recent data released by the World Health Organization show that close to one-third of the world population still lacks access to safely managed water in 2015 [1]. Waterborne pathogens lead to the spread of diseases, a major cause of death among children in developing regions [2,3]. Many areas around the world, especially in developing countries, lack the infrastructure to provide clean, reliable water, forcing some people to drink unsafe water, which can cause public health risks. As the human population continues to grow, the availability of safe, clean water will become increasingly stringent, and thus new water disinfection technologies that are suitable for use in the developing and rural regions are in particularly urgent demand $[4,5]$.

Methods available for disinfection in distributed point-of-use applications are limited. Chemical disinfection methods involve strong oxidative agents like ozone, chlorine, sodium hypochlorite, or chlorine dioxide that are hazardous to ship and handle, making them not feasible for distributed point-of-use applications at rural places, even those in developed countries [5]. UV treatment is used in limited cases for distributed disinfection applications, but its effectiveness is largely reduced by light dissipation [6]. Solar water disinfection (SODIS) has been adopted in some developing areas for point-of-use treatment, but its performance is highly dependent on the intensity of sunlight and the sensitivity of the pathogens [7]. Chemical disinfection methods have been used in centralized water treatment plants in addition to the other conventional physicochemical processes [8], but it is 
associated with the concern of forming undesired disinfection by-products (DBPs) in treated water that might be carcinogenic [9-11]. Regardless, these methods cannot be used in many regions of the world because of the lack of appropriate infrastructure [12]. Alternative disinfection approaches with minimal DBPs as well as ease of use are needed, especially for distributed point-of-use applications.

Reactive electrochemical membrane (REM) filtration is an innovative water treatment technique achieved by passing water through a membrane that also acts as an anode, thus combining filtration with various electrochemical effects for water disinfection [13-18]. REM does not involve chemical addition and can be easily operated and driven by solar power, making it potentially suitable for point-of-use water disinfection. Currently, only a few membranes have been tested for REM application in water disinfection (e.g., silver nanowire [19], copper oxides [13], and carbon nanotubes [20]). However, these membrane materials suffer serious limitations, including the possible release of toxic ions such as silver and copper, and unfavorable filtration flow conditions with carbon nanotube filters.

Activated carbon fiber cloth (ACFC) is a form of processed carbon that is hydrophobic, porous, conductive, and environmentally benign [21], making it a good candidate for REM application. However, the use of ACFC as membrane in REM applications has not been studied. Escherichia coli is one of the major enteric pathogens that cause severe diseases [2]. The current work was conducted to verify and explore the effectiveness of ACFC as the membrane in REM treatment to disinfect pathogens in water using non-pathogenic E. coli as a model bacterium.

\section{Materials and Method}

\subsection{REM Setup and Operation}

The experiment was conducted by passing a solution inoculated with E. coli (ATCC 15597 obtained from American Type Culture Collection, Manassas, Virginia) through an REM device with multiple layers of ACFC as the anode to which voltage was applied. Bacteria concentration was determined by plating the effluent using Luria-Bertani (LB) agar solid medium (Sigma-Aldrich) and counting the colonies formed after incubation. Single-weave ACFC (zorflex ${ }^{\circledR}$ ) was obtained from Calgon Carbon (Pittsburg, PA, USA). It has a large surface area of $1000-2000 \mathrm{~m}^{2} / \mathrm{g}$ as a highly microporous material, although its geometric area is only about $6.67 \times 10^{-3} \mathrm{~m}^{2} / \mathrm{g}$. The cloth was cut into circular pieces (3-cm diameter) to fit in the REM filtration device that was custom-made and set up as indicated in Figure 1. The effective flow cross section area is $7.07 \times 10^{-4} \mathrm{~m}^{2}$. DC power was supplied to the REM device using a 303DM DC power supply (Electro Industries Inc., Monticello, MN, USA) in constant voltage mode with the ACFC placed in contact with a mixed metal oxide (MMO) grid as the anode and another MMO grid in parallel as the cathode. A ring-shaped rubber separator of $1.25-\mathrm{cm}$ thickness was placed between the anode and cathode. The MMO grid is made of titanium coated with iridium-ruthenium oxide, which is known as a dimensionally stable anode (DSA) material and has been widely used in water treatment applications [22,23]. The MMO grids were used in the REM device both as a contactor on the anode and as the cathode because of their good conductivity and stability. All materials involved in REM treatment, including the components in the REM device, silicon tubing, and a flask as the feed tank were autoclaved at $121^{\circ} \mathrm{C}$ for $30 \mathrm{~min}$ prior to each disinfection experiment. 

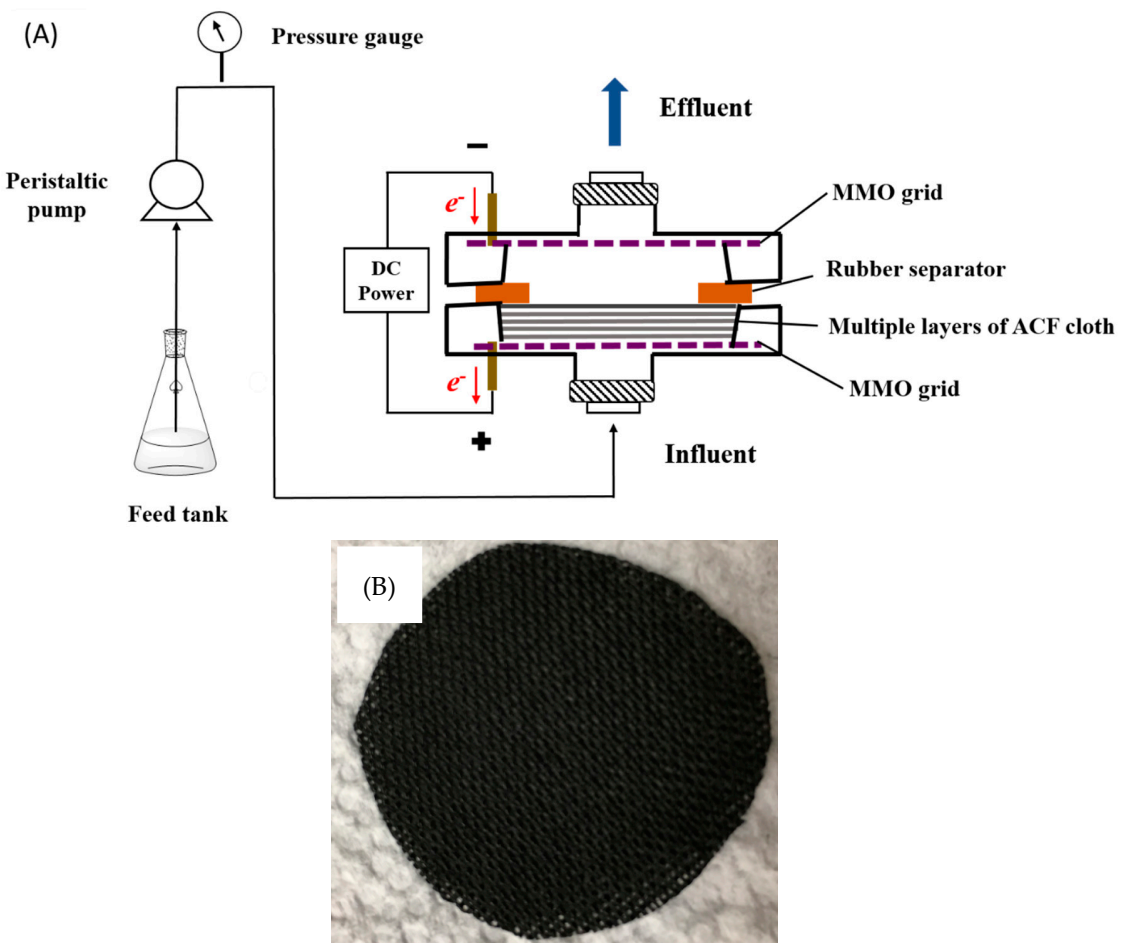

Figure 1. (A) A schematic diagram of the REM operation and (B) a picture of activated carbon fiber cloth (ACFC). MMO: mixed metal oxide.

For the disinfection experiment, E. coli was inoculated at approximately $10^{7}$ cells $/ \mathrm{mL}$ in a solution of $50 \mathrm{mM} \mathrm{Na}_{2} \mathrm{SO}_{4}$ as the supporting electrolyte. All E. coli solution was freshly prepared by first mixing the culture in $\mathrm{LB}$ medium at $37^{\circ} \mathrm{C}$ overnight and then diluting it to the desired concentration with a $50 \mathrm{mM} \mathrm{Na}_{2} \mathrm{SO}_{4}$ solution prepared using deionized (DI) water with a resistivity of $<18 \mathrm{M} \Omega$ $\mathrm{cm}$ (Barnstead NANOpure water purification system, Waltham, MA, USA). The solution was then placed in a feed tank and pumped through the REM device via silicon tubing at a prescribed flow rate (1-20 mL/min) using a Masterflex L/S peristaltic pump (Cole Parmer, Vernon Hills, IL, USA), while a voltage $(0-20 \mathrm{~V})$ was applied to the device. After the first $5.0 \mathrm{~mL}$ of effluent was passed through, a sample was collected in a sterilized tube for E. coli concentration determination. All the disinfection treatments were carried out at room temperature, and the activated carbon fiber cloth was replaced prior to each new test to ensure consistent results.

\subsection{Effect of Various Factors on Disinfection Efficiency}

REM treatments were performed with varying operating conditions, including applied voltage, number of ACFC layers, flow rate, and operation time. In each set of experiments, one condition was varied with the other conditions kept constant. The conditions that were tested are listed in Table 1. An E. coli cell suspension of approximately $10^{7}$ cells $/ \mathrm{mL}$ was passed through the REM device unless otherwise specified. Bacterial log reduction was calculated by taking the logarithm of the ratio between the bacterial concentrations in the sample before and after treatment.

\subsection{Measurement of E. coli Concentration}

The E. coli samples before and after disinfection treatment were serially diluted using $0.9 \%$ sterilized $\mathrm{NaCl}$ solution. Then, $0.1 \mathrm{~mL}$ of the diluted sample was plated on $\mathrm{LB}$ agar plate. The plate was covered with parafilm and incubated at $37^{\circ} \mathrm{C}$ for about $24 \mathrm{~h}$, and then the number of colonies on the agar plate was counted to calculate the colony forming units per $\mathrm{mL}(\mathrm{CFU} / \mathrm{mL})$ for each sample [24]. Each condition was tested in triplicate, for which the mean and standard deviation were calculated and are shown in the figures. 


\subsection{Energy Consumption}

Unit energy consumption (UEC) is defined as the energy consumption per unit volume per log reduction of E. coli, which can be calculated by Equation (1),

$$
\mathrm{UEC}=\frac{E}{V l}=\frac{U I}{60 r l}
$$

where $E$ represents energy $(\mathrm{kWh}), V$ volume $(\mathrm{L}), l$ the log reduction of $E$. coli., $U$ the applied cell voltage $(\mathrm{V}), I$ the electric current $(\mathrm{A})$, and $r$ the flow rate $(\mathrm{mL} / \mathrm{min})$ for the treatment.

\subsection{Measurement of Anodic Potentials}

The REM device was immersed in $30 \mathrm{~mL}$ of a $50 \mathrm{mM} \mathrm{Na}_{2} \mathrm{SO}_{4}$ solution, with different cell voltage applied to the REM electrodes. The anodic potential was measured versus a leak-free $\mathrm{Ag} / \mathrm{AgCl}$ reference electrode (Warner Instruments, LF-100) placed $0.85 \mathrm{~mm}$ from the anode surface using a CHI 660E electrochemical workstation (Austin, TX, USA). All potentials were reported versus the standard hydrogen electrode (SHE).

The linear scan voltammetry (LSV) analyses were conducted using ACFC as the anode, a platinum foil of the same size as the counter electrode, and a leak-free $\mathrm{Ag} / \mathrm{AgCl}$ electrode as the reference electrode in $30 \mathrm{~mL}$ of a $50 \mathrm{mM} \mathrm{Na}_{2} \mathrm{SO}_{4}$ solution, at a scan rate of $50 \mathrm{mV} \mathrm{s}^{-1}$ driven by the $\mathrm{CHI} 660 \mathrm{E}$ electrochemical workstation (Austin, TX, USA).

\subsection{Quantification of Hydroxyl Free Radicals}

An additional experiment was performed to quantify the steady-state concentration of hydroxyl free radicals $([\bullet \mathrm{OH}] \mathrm{ss})$ that may be formed on the anode in the REM device, using terephthalic acid (TA) as a free radical probe $[16,25]$. The REM device was immersed in $30 \mathrm{~mL}$ of a $50 \mathrm{mM} \mathrm{Na}_{2} \mathrm{SO}_{4}$ solution containing $10 \mu \mathrm{M}$ TA, with $10 \mathrm{~V}$ applied to the REM electrodes. At prescribed time intervals $(0,5,15,30,60$, and $120 \mathrm{~min}), 0.5 \mathrm{~mL}$ samples were taken and analyzed by High-Performance Liquid Chromatography (HPLC) to quantify TA as described below.

\subsection{Analytical Methods}

A Shimadzu LC 20TA HPLC equipped with a Shimadzu SPD-M20A Photo Diode Array (PDA) was used to quantify TA concentrations. The separation was performed on an Ascentic C18 reversed phase column $(250 \times 4 \mathrm{~mm}, 5 \mu \mathrm{m}$ particle, Supelco), and injection volume was $10 \mu \mathrm{L}$. A binary mobile phase consisting of methanol with $0.1 \%$ formic acid and water with $0.1 \%$ formic acid (1:1 volume ratio) was used at the flow rate of $0.8 \mathrm{~mL} / \mathrm{min}$.

\section{Results and Discussion}

\subsection{Disinfection under Different Operation Conditions}

The disinfection effect of REM treatment was evaluated with three key operating factors varied, including the number of ACFC layers, cell voltage, and flow rate. The conditions that have been tested are summarized in Table 1, and the results are displayed in Figure 2 and also listed in Table 1. As seen in Figure 2A, the log reduction of E. coli increased with the addition of ACFC layers from 0 to 8 . There was an approximately $1.6 \log$ reduction without ACFC, $2.4 \log$ reduction with 1 ACFC layer employed, and the $\log$ reduction of bacteria was 7.5 with both 4 and 8 layers, where the added E. coli were completely killed. Apparently, the disinfection effect increased with the increase of ACFC layers, while the $1.6 \mathrm{log}$ reduction without ACFC may have been caused by the electrochemical effect of the MMO grid. Our tests indicated that the bacteria concentration was stable in the feed tank during the test. 
Table 1. The conditions of REM treatment experiments and the results of bacterial log reduction. The conditions that were varied in each test series are indicated in bold.

\begin{tabular}{ccccc}
\hline ACFC Layers & Cell Voltage $(\mathbf{V})$ & Flow Rate $(\mathbf{m L} / \mathbf{m i n})$ & Log Reduction & Standard Deviation \\
\hline $\mathbf{0}$ & 10 & 10 & 1.61 & 0.59 \\
$\mathbf{1}$ & 10 & 10 & 2.42 & 0.15 \\
$\mathbf{4}$ & 10 & 10 & 7.53 & 0.00 \\
$\mathbf{8}$ & 10 & 10 & 7.53 & 0.00 \\
$\mathbf{4}$ & $\mathbf{0}$ & 10 & 0.35 & 0.06 \\
$\mathbf{2}$ & $\mathbf{2}$ & 10 & 0.47 & 0.16 \\
4 & $\mathbf{5}$ & 10 & 1.43 & 0.17 \\
4 & $\mathbf{1 0}$ & 10 & 7.28 & 0.00 \\
$\mathbf{2 0}$ & 10 & 7.28 & 0.00 \\
$\mathbf{4}$ & 10 & $\mathbf{1}$ & 6.74 & 0.00 \\
4 & 10 & $\mathbf{5}$ & 6.74 & 0.00 \\
$\mathbf{4}$ & 10 & $\mathbf{1 0}$ & 6.74 & 0.00 \\
$\mathbf{4}$ & $\mathbf{2 0}$ & 3.18 & 0.01 \\
\hline
\end{tabular}
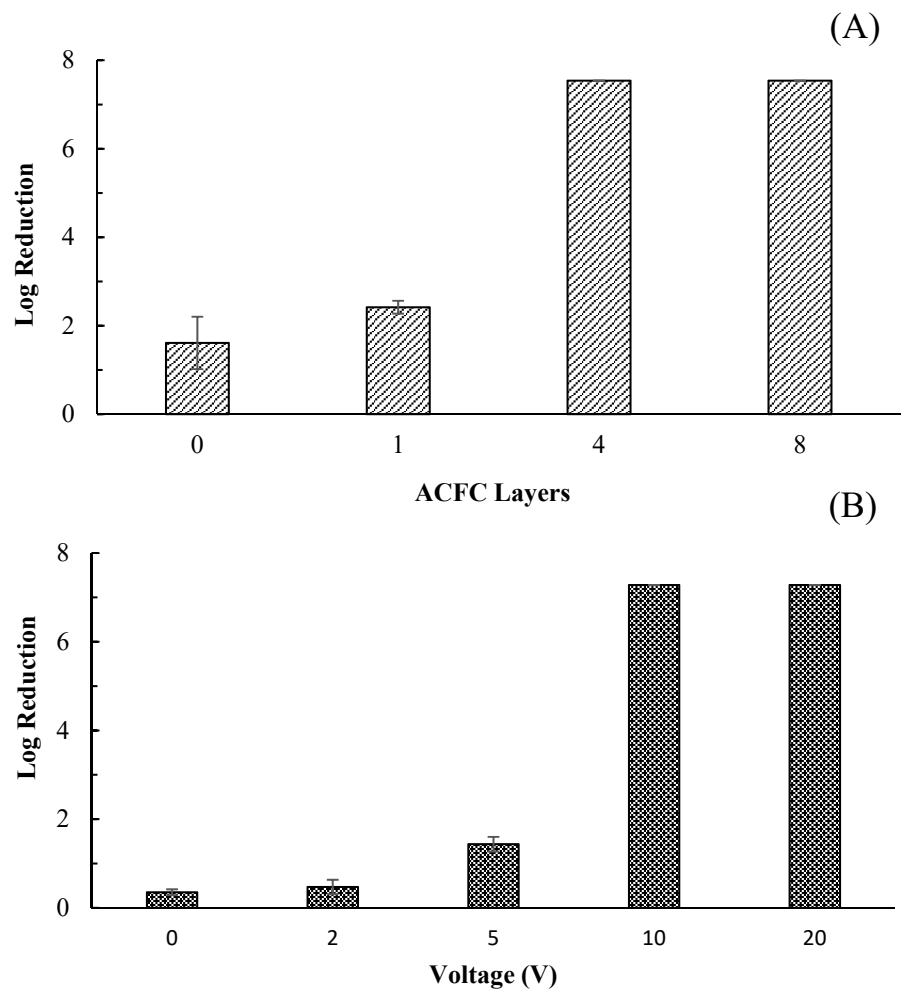

(C)

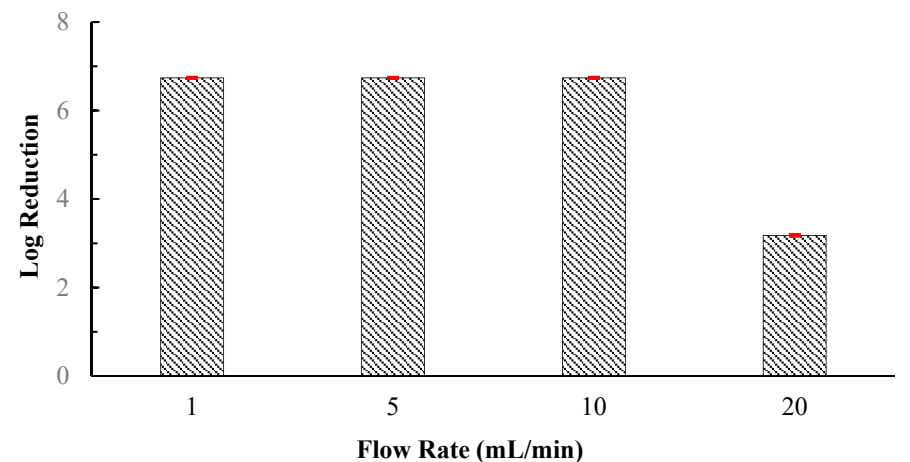

Figure 2. Bacterial log reduction by REM treatment at different conditions: (A) different ACFC layers at $10 \mathrm{~V}$ cell voltage and $10 \mathrm{~mL} / \mathrm{min}$ flow rate; (B) different voltage with 4 ACFC layers and $10 \mathrm{~mL} / \mathrm{min}$ flow rate; (C) different flow rate with $4 \mathrm{ACFC}$ layers and at $10 \mathrm{~V}$ cell voltage. The initial E. coli concentration was $10^{7.5}, 10^{7.3}$, and $10^{6.7} \mathrm{CFU} / \mathrm{mL}$ for the tests in $(\mathrm{A}),(\mathrm{B})$, and $(\mathrm{C})$, respectively. 
The higher voltage led to an increased disinfection of the REM with four layers of ACFC (Figure 2B). Without any potential applied, a $0.4 \mathrm{log}$ reduction was observed, which could result from the retention of $E$. coli by ACFC layers [26]. Disinfection was enhanced to 0.5, 1.4, 7.3, and $7.3 \mathrm{log}$ reduction for the applied voltages of $2,5,10$, and $20 \mathrm{~V}$, respectively, where the log reduction of 7.3 represented complete disinfection. A similar phenomenon was documented in an earlier study with REM using a sub-stoichiometric titanium oxide as the membrane [26].

Figure $2 \mathrm{C}$ shows the effect of flow rate on the reduction of E. coli concentration in the effluent after treatment by REM with 4 ACFC layers and $10 \mathrm{~V}$ applied voltage. It seems that the flow rate did not impact the disinfection performance much when the flow rate was in the range of 1 to $10 \mathrm{~mL} / \mathrm{min}$, with the $\log$ reduction remaining at 6.7 for the flow rates of 1,5 , and $10 \mathrm{~mL} / \mathrm{min}$, respectively, where all the added $E$. coli were killed. When the flow rate increased to $20 \mathrm{~mL} / \mathrm{min}$, the disinfection performance was reduced to $3.2 \mathrm{log}$ reduction. The flow rate of $10 \mathrm{~mL} / \mathrm{min}$ corresponds to a linear flow velocity of $2.4 \times 10^{-4} \mathrm{~m} / \mathrm{s}$ with a $7.07 \times 10^{-4} \mathrm{~m}^{2}$ effective flow cross-sectional area. For a REM device with an effective cross-sectional area of $7.07 \times 10^{-2} \mathrm{~m}^{2}$, it would take only $1.5 \mathrm{~min}$ to treat $1.5 \mathrm{~L}$ of water, estimated to be the daily consumption of drinking water for an adult [27].

Activated carbon fiber (ACF) is a form of processed carbon that is both hydrophobic and microporous, allowing it to adsorb bacteria [21]. In addition, it conducts electricity, thus enabling it usable as a membrane electrode in REM applications, as demonstrated in the results of this study. ACF is a widely available material that is cheaper and easier to produce than carbon nanotubes, and is environmentally benign. ACF can be easily made into woven or nonwoven fabrics, such as activated carbon fiber cloth (ACFC). Unlike carbon nanotubes, ACFC can be easily handled and used as a membrane to achieve controllable flow conditions. A nearly $7.5 \log$ unit reduction in E. coli concentration could be achieved by the REM treatment in this study using ACFC as the membrane. This is better than the results from earlier reports with different REM membrane materials, although a direct comparison is not possible because of different treatment conditions. A near $6.5 \log$ CFU decay was achieved for $E$. coli with the use of a sub-stoichiometric titanium oxide ceramic membrane in REM [28], and only over 2 log CFU reduction was obtained for E. coli when treated by a fluidized bed electrode composed of granular activated carbon under an alternating electric field with a double modulated frequency of 10 and $140 \mathrm{kHz}$ for $6 \mathrm{~h} \mathrm{[6].}$

\subsection{Disinfection under Continuous REM Operation}

REM was operated continuously with a total of $2.4 \mathrm{~L}$ E. coli solution treated using $10 \mathrm{~V}$ cell voltage at a flow rate of $10 \mathrm{~mL} / \mathrm{min}$ with 4 or 8 layers of ACFC, and the effluent was collected at different time intervals to measure the change of $E$. coli concentration over time (Figure 3). The disinfection efficiency decreased over time for both 4 and 8 layers during the continuous operation as seen in Figure 3, with the performance of 8 layers being slightly better than that of 4 layers. This is possibly due to the gradual accumulation of cells on ACFC, preventing more E. coli from contact and thus limiting its electrochemical disinfection effect. During the test, samples were taken from the feed tank to measure E. coli concentration, and the result showed that no observable bacterial growth or decay occurred in the feed tank within the $4 \mathrm{~h}$ of operation. 


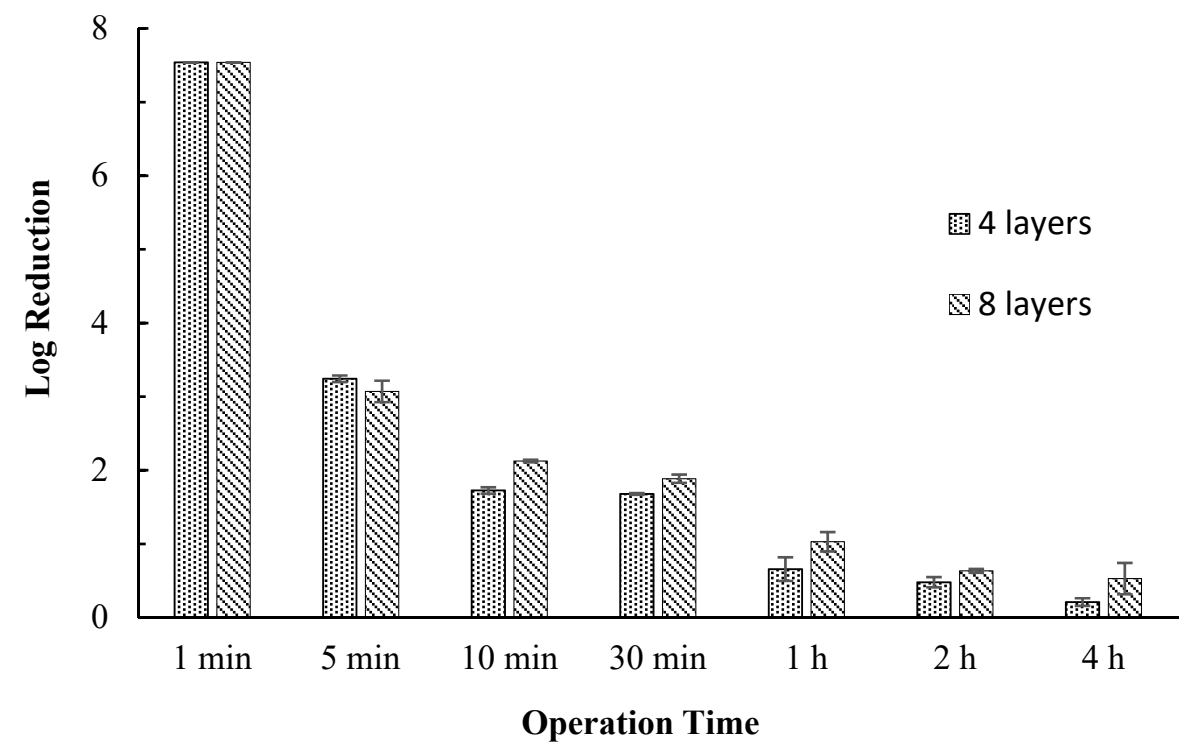

Figure 3. Bacterial log reduction by REM treatment with 4 or 8 ACFC layers at $10 \mathrm{~mL} / \mathrm{min}$ and $10 \mathrm{~V}$ under continuous operation.

\subsection{Energy Consumption}

Energy input is an important factor when considering effectiveness for application. The unit energy consumption (UEC), defined as the energy consumption per unit volume per log reduction of E. coli, was calculated for all treatments with 4 ACFC layers shown in Table 1 and presented in Figure 4. The UEC decreased as the flow rate increased and as the applied voltage decreased. The UEC for REM treatment was found to be $0.0015 \mathrm{kWh} / \mathrm{L}$ (i.e., $1.5 \mathrm{kWh} / \mathrm{m}^{3}$ ) with 4 layers of ACFC at $10 \mathrm{~mL} / \mathrm{min}$ and $10 \mathrm{~V}$, which was among the conditions achieving complete bacterial disinfection as seen in Figure 2. Such an energy consumption level makes it possible to drive the ACFC-based REM with solar energy. At least a $2.2 \mathrm{kWh} / \mathrm{L}$ energy requirement has been reported for above $2 \log$ units reduction of $E$. coli using the fluidized bed electrode of granular activated carbon [6].

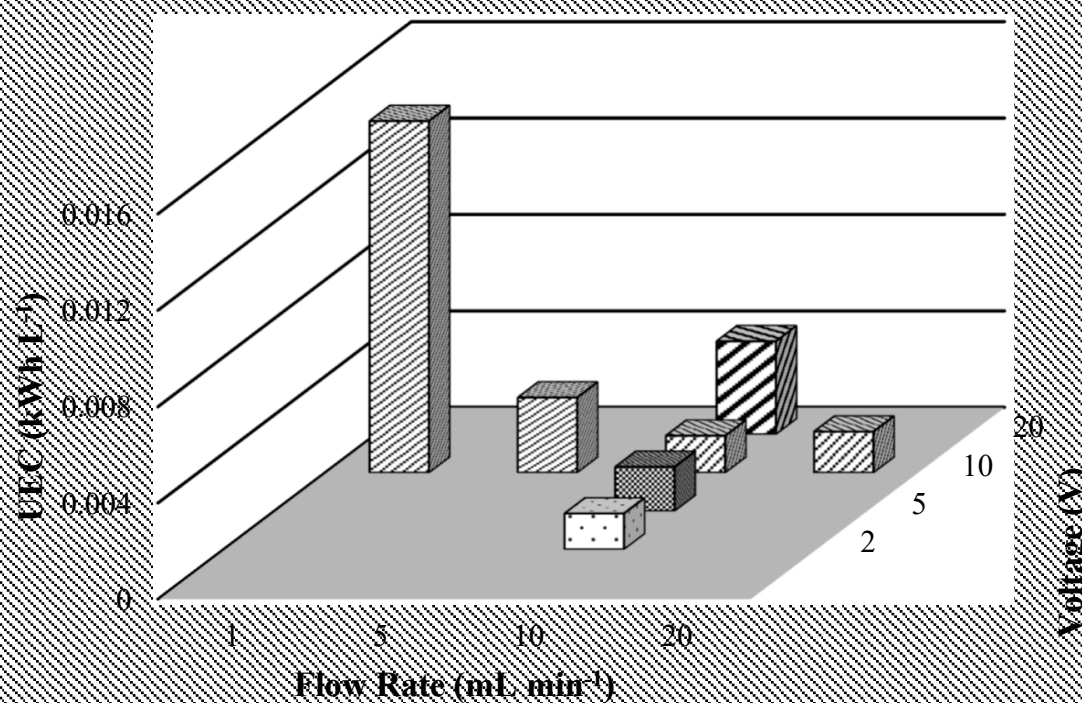

Figure 4. Unit energy consumption (UEC) of REM under different operation conditions with 4 ACFC layers. 


\subsection{Possible Mechanisms}

The anodic potentials of REM were measured under different applied cell voltages and are plotted in Figure 5A. The cell voltages of 2.0 and $5.0 \mathrm{~V}$, between which the disinfection performance started to rise as shown in Figure 2B, correspond to the anodic potentials of 0.91 and $1.71 \mathrm{~V}$ vs. SHE, respectively, as seen in Figure 5A. The LSV of ACFC in $50 \mathrm{mM} \mathrm{Na}_{2} \mathrm{SO}_{4}$ solution (Figure 5B) revealed the oxygen evolution potential (OEP) to be $1.35 \mathrm{~V}$ vs. SHE. Therefore, the disinfection performance was promoted around the anodic potential where water oxidation reactions intensified. The anodic oxidation of water can generate hydroxyl radicals that are known to disinfect pathogens by reacting with unsaturated membrane lipids to destruct membrane structure and cell integrity to further cause cell lysis and protein release [29]. In addition to hydroxyl radicals, other reactive oxygen species (ROS) such as ozone and hydrogen peroxide may also be formed during anodic water oxidation. They can also disinfect pathogens, albeit less effectively than hydroxyl radicals [30-32].

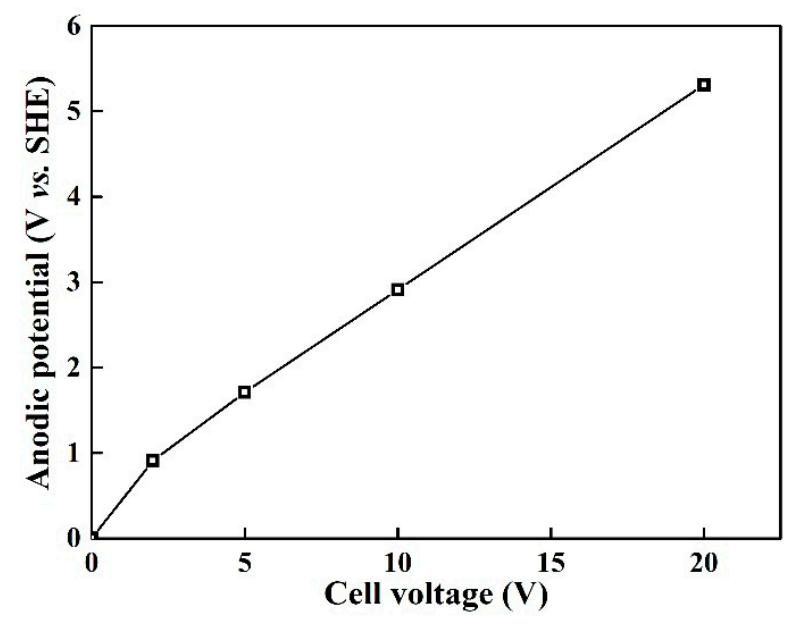

(A)

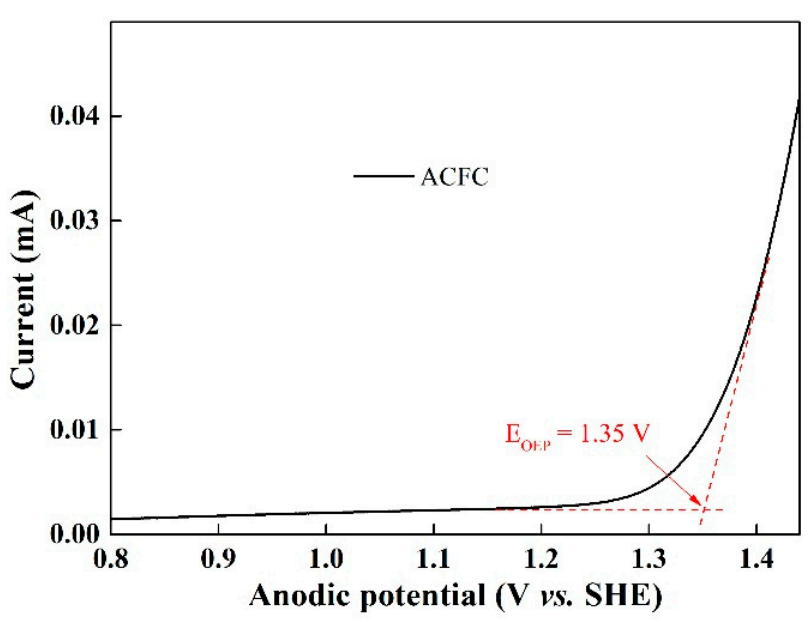

(B)

Figure 5. (A) The anodic potential vs. SHE (V) at different cell voltage; (B) Linear scan voltammetry of ACFC in $50 \mathrm{mM} \mathrm{Na}_{2} \mathrm{SO}_{4}$ solution at the scanning rate of $50 \mathrm{mV} \mathrm{s}^{-1}$.

The steady-state concentrations of hydroxyl radicals $([\bullet \mathrm{OH}] \mathrm{ss})$ that were produced in the REM system were quantified using terephthalic acid (TA) as a radical probe with 4 ACFC layers under $10 \mathrm{~V}$ cell voltage. The TA disappearance over time was plotted in Figure 6, based on which the 
pseudo-first-order rate constant $\left(\mathrm{k}_{\mathrm{TA}}\right)$ could be obtained by data fitting. The $[\bullet \mathrm{OH}] \mathrm{ss}$ was then calculated using the following equation:

$$
[\bullet \mathrm{OH}] \mathrm{ss}=\frac{\mathrm{k}_{\mathrm{TA}}}{\mathrm{k}_{\bullet} \mathrm{OH}, \mathrm{TA}}
$$

where $k_{\bullet} \mathrm{OH}, \mathrm{TA}$ is the second-order reaction rate constant between $\bullet \mathrm{OH}$ and TA $\left(4.4 \times 10^{9} \mathrm{M}^{-1} \mathrm{~s}^{-1}\right)$ [25]. The $[\bullet \mathrm{OH}]$ ss was determined to be $0.8 \times 10^{-13} \mathrm{M}$. In order to distinguish if the hydroxyl free radicals were generated from the ACFC or the MMO grid, the same TA probing test was conducted for the REM device without an ACFC layer in place. TA did not disappear in this system, as shown in Figure 6, and, according to Equation (2), the $[\bullet \mathrm{OH}]$ ss was 0 in this case. This suggests that hydroxyl radicals were mainly produced by ACFC rather than the MMO grid in the REM device. The MMO grid is coated with iridium-ruthenium oxide, which is known to be a material that facilitates anodic water oxidation without effective $\bullet \mathrm{OH}$ production $[23,33$. The moderate disinfection effect of REM without an ACFC layer as shown in Figure 2 may have resulted from ROS other than $\bullet \mathrm{OH}$, such as hydrogen peroxide, that were formed during water oxidation. The increase in ACFC layers promoted $\bullet \mathrm{OH}$ production and thus enhanced disinfection performance. In addition, more ACFC layers increased bacterial retention and thus contact time on the anode, therefore also enhancing disinfection.

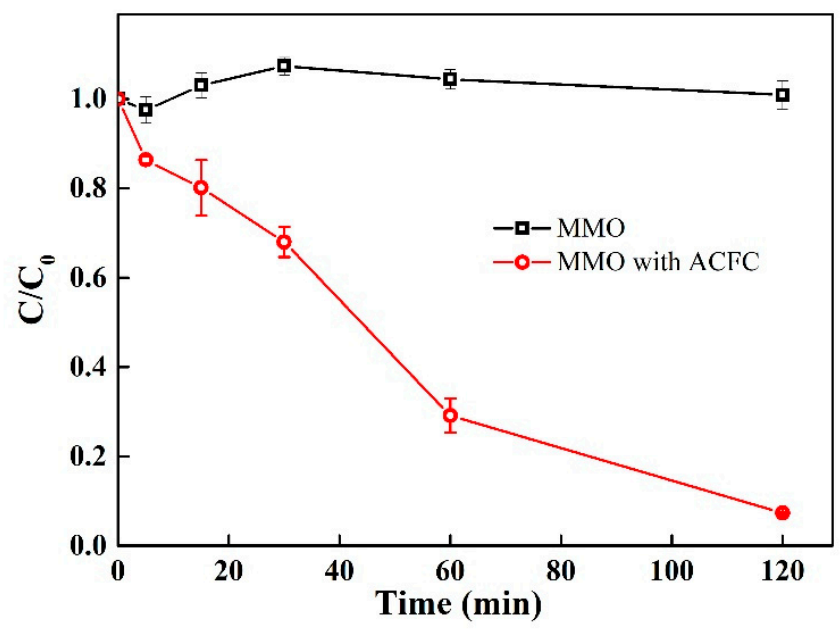

Figure 6. The loss of TA in $30 \mathrm{~mL}$ of a $50 \mathrm{mM} \mathrm{Na}_{2} \mathrm{SO}_{4}$ solution with $\mathrm{MMO}$ grid as the anode or MMO grid with four ACFC layers as the anode, respectively. Error bars represent standard deviations $(n=3)$. $\mathrm{C}_{0}=10 \mu \mathrm{M}$, cell voltage $=10 \mathrm{~V}$.

The SEM images of ACFC from REM after passing E. coli solution $(10 \mathrm{~mL} / \mathrm{min})$ both with or without voltage $(10 \mathrm{~V})$ applied were obtained. The microstructure of the ACFC is evident in Figure 7. Without voltage applied, few E. coli and $\mathrm{Na}_{2} \mathrm{SO}_{4}$ crystals were found attached on the surface of the ACFC (Figure 7A). The treatment with $10 \mathrm{~V}$ applied obviously resulted in the increased attachment of E. coli remnants, which might be damaged in cell structure by the ROS generated on the ACFC (Figure 7B). No intact E. coli can be found on the ACFC in all pictures taken. 
(A)

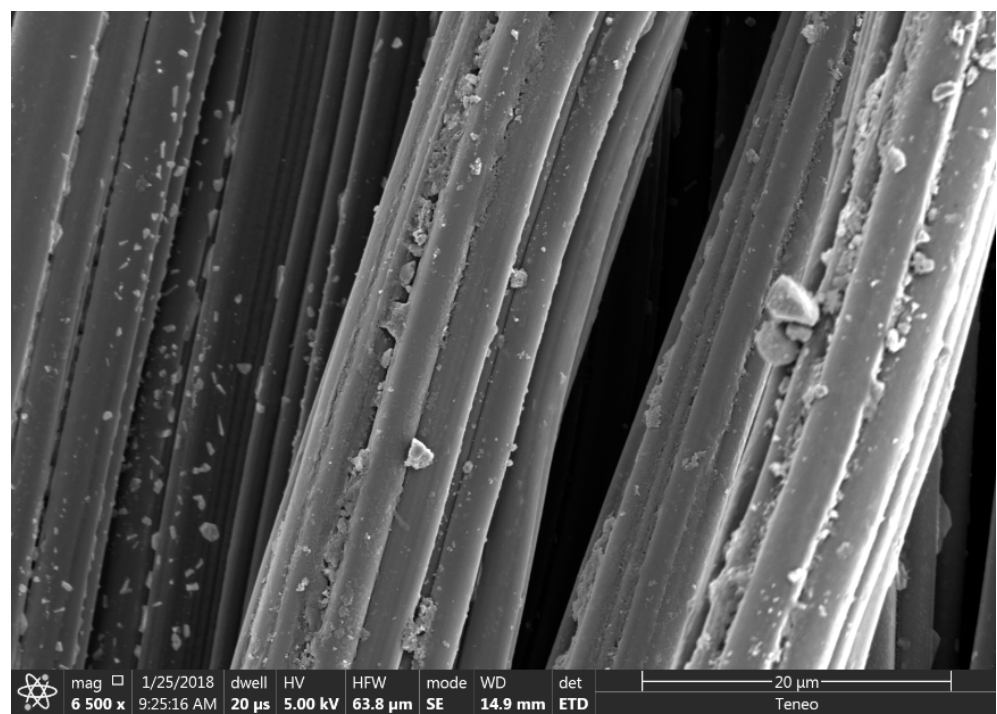

(B)

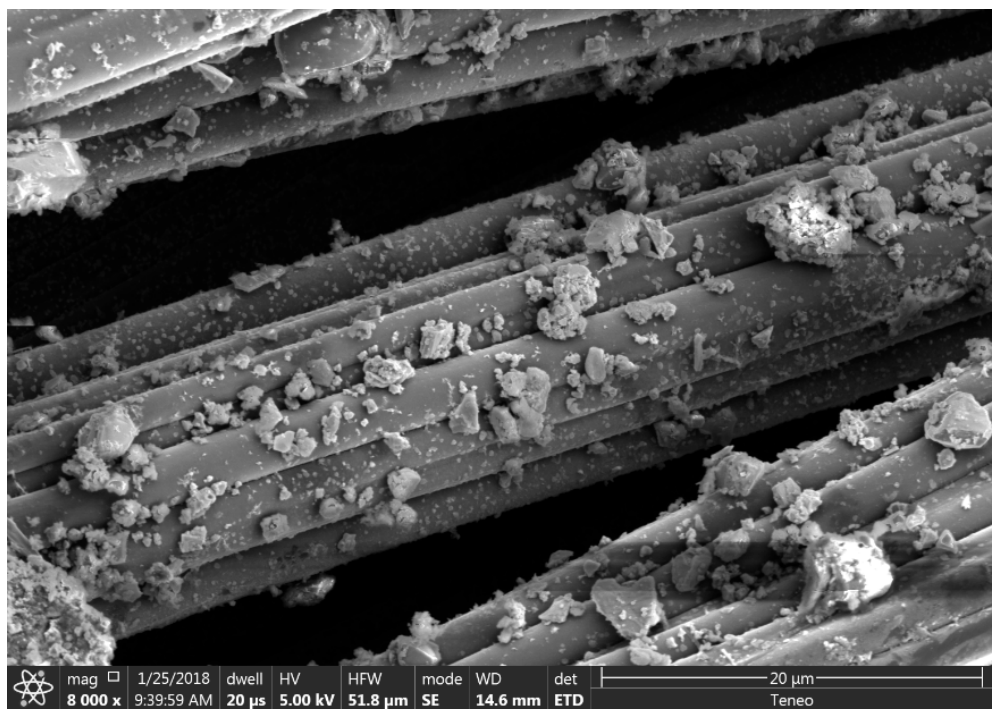

Figure 7. SEM images of ACFC from REM after passing E. coli solution $\left(\sim 10^{4} \mathrm{CFU} / \mathrm{mL}\right)$ in $50 \mathrm{mM}$ $\mathrm{Na}_{2} \mathrm{SO}_{4}$ solution at $10 \mathrm{~mL} / \mathrm{min}$ with (A) no voltage and (B) $10 \mathrm{~V}$ applied.

\section{Conclusions}

REM using ACFC as the membrane achieved superb reduction of E. coli (up to 7.5 log unit reduction), likely through the combined effects of retention of bacteria on ACFC and the oxidation by $\bullet \mathrm{OH}$ and other ROS generated electrochemically on the anode. The disinfection effect was shown to be dependent on the number of ACFC layers, voltage, flow rate, as well as operation time. ACFC is a widely available, environmentally benign, and low-cost material. REM is a versatile energy-efficient process that can be driven by solar energy. The results indicate the great potential of an ACFC-based REM process for point-of-use water disinfection, particularly for rural, developing regions. The efficiency of this disinfection method may be influenced by the composition of source water (e.g., suspended solids and organic matter), which warrants further exploration.

Author Contributions: All authors collaborated on this work. Conceptualization, E.H. and H.S.; Methodology, E.H., T.W., H.S., and J.L.; Formal Analysis, E.H., J.L., and B.W.; Writing-Original Draft Preparation, E.H.; Writing-Review \& Editing, J.L., H.S., and E.H.

Funding: This research received no external funding.

Acknowledgments: Shangtao Liang is acknowledged for providing technical assistance and helpful discussion. 
Conflicts of Interest: The authors declare no conflict of interest.

\section{References}

1. WHO. 2017. Available online: http://www.who.int/gho/mdg/environmental_sustainability/water/en/ (accessed on 8 January 2019).

2. Ashbolt, N.J. Microbial contamination of drinking water and disease outcomes in developing regions. Toxicology 2004, 198, 229-238. [CrossRef] [PubMed]

3. Ashbolt, N.J. Microbial Contamination of Drinking Water and Human Health from Community Water Systems. Curr. Environ. Health Rep. 2015, 2, 95-106. [CrossRef] [PubMed]

4. Mwabi, J.K.; Adeyemo, F.E.; Mahlangu, T.O.; Mamba, B.B.; Brouckaert, B.M.; Swartz, C.D.; Offringa, G.; Mpenyana-Monyatsi, L.; Momba, M.N.B. Household water treatment systems: A solution to the production of safe drinking water by the low-income communities of Southern Africa. Phys. Chem. Earth. 2011, 36, 1120-1128. [CrossRef]

5. Schiermeier, Q. Water: Purification with a pinch of salt. Nature 2008, 452, 260-261. [CrossRef] [PubMed]

6. Racyte, J.; Bernard, S.; Paulitsch-Fuchs, A.H.; Yntema, D.R.; Bruning, H.; Rijnaarts, H.H.M. Alternating electric fields combined with activated carbon for disinfection of Gram negative and Gram positive bacteria in fluidized bed electrode system. Water Res. 2013, 47, 6395-6405. [CrossRef] [PubMed]

7. McGuigan, K.G.; Conroy, R.M.; Mosler, H.-J.; Preez, M.D.; Ubomba-Jaswa, E.; Fernandez-Ibañez, P. Solar water disinfection (SODIS): A review from bench-top to roof-top. J. Hazard. Mater. 2012, 235-236, $29-46$. [CrossRef] [PubMed]

8. Kraft, A. Electrochemical Water Disinfection: A Short Review. Platin. Met. Rev. 2008, 52, 177-185. [CrossRef]

9. Szczuka, A.; Parker, K.M.; Harvey, C.; Hayes, E.; Vengosh, A.; Mitch, W.A. Regulated and unregulated halogenated disinfection byproduct formation from chlorination of saline groundwater. Water Res. 2017, 122, 633-644. [CrossRef] [PubMed]

10. Chuang, Y.H.; Mitch, W.A. Effect of ozonation and biological activated carbon treatment of wastewater effluents on formation of N-nitrosamines and halogenated disinfection byproducts. Environ. Sci. Technol. 2017, 51, 2329-2338. [CrossRef] [PubMed]

11. Zhang, Z.X.; Zhao, Q.; Liu, Y.L.; Ma, J.; Qi, J.Y.; Ren, Z.J. Determination of twelve kinds of volatile disinfection byproducts in drinking water by gas chromatography with electron capture detector. Chin. J. Anal. Chem. 2017, 45, 1203-1208.

12. Shannon, M.A.; Bohn, P.W.; Elimelech, M.; Georgiadis, J.G.; Marinas, B.J.; Mayes, A.M. Science and technology for water purification in the coming decades. Nature 2008, 452, 301-311. [CrossRef] [PubMed]

13. Huo, Z.-Y.; Xie, X.; Yu, T.; Lu, Y.; Feng, C.; Hu, H.-Y. Nanowire-modified three-dimensional electrode enabling low-voltage electroporation for water disinfection. Environ. Sci. Technol. 2016, 50, 7641-7649. [CrossRef] [PubMed]

14. Liu, C.; Xie, X.; Zhao, W.; Yao, J.; Kong, D.; Boehm, A.B.; Cui, Y. Static electricity powered copper oxide nanowire microbicidal electroporation for water disinfection. Nano Lett. 2014, 14, 5603-5608. [CrossRef] [PubMed]

15. Vecitis, C.D.; Schnoor, M.H.; Rahaman, M.S.; Schiffman, J.D.; Elimelech, M. Electrochemical multiwalled carbon nanotube filter for viral and bacterial removal and inactivation. Environ. Sci. Technol. 2011, 45, 3672-3679. [CrossRef] [PubMed]

16. Gayen, P.; Chen, C.; Abiade, J.T.; Chaplin, B.P. Electrochemical Oxidation of Atrazine and Clothianidin on Bi-doped $\mathrm{SnO}_{2}-\mathrm{Ti}_{\mathrm{n}} \mathrm{O}_{2 \mathrm{n}-1}$ Electrocatalytic Reactive Electrochemical Membranes. Environ. Sci. Technol. 2018, 52, 12675-12684. [CrossRef] [PubMed]

17. Liu, S.; Wang, Y.; Zhou, X.; Han, W.; Li, J.; Sun, X.; Shen, J.; Wang, L. Improved degradation of the aqueous flutriafol using a nanostructure macroporous $\mathrm{PbO}_{2}$ as reactive electrochemical membrane. Electrochim. Acta 2017, 253, 357-367. [CrossRef]

18. Trellu, C.; Chaplin, B.P.; Coetsier, C.; Esmilaire, R.; Cerneaux, S.; Causserand, C.; Cretin, M. Electro-oxidation of organic pollutants by reactive electrochemical membranes. Chemosphere 2018, 208, 159-175. [CrossRef] [PubMed] 
19. Wen, J.; Tan, X.; Hu, Y.; Guo, Q.; Hong, X. Filtration and Electrochemical Disinfection Performance of PAN/PANI/AgNWs-CC Composite Nanofiber Membrane. Environ. Sci. Technol. 2017, 51, 6395-6403. [CrossRef] [PubMed]

20. Rahaman, M.S.; Vecitis, C.D.; Elimelech, M. Electrochemical Carbon-Nanotube Filter Performance toward Virus Removal and Inactivation in the Presence of Natural Organic Matter. Environ. Sci. Technol. 2012, 46, 1556-1564. [CrossRef] [PubMed]

21. Prajapati, Y.N.; Bhaduri, B.; Joshi, H.C.; Srivastava, A.; Verma, N. Aqueous phase adsorption of different sized molecules on activated carbon fibers: Effect of textural properties. Chemosphere 2016, 155, 62-69. [CrossRef] [PubMed]

22. Rao, A.N.S.; Venkatarangaiah, V.T. Metal oxide-coated anodes in wastewater treatment. Environ. Sci. Pollut. R 2014, 21, 3197-3217.

23. Kenova, T.A.; Kornienko, G.V.; Golubtsova, O.A.; Kornienko, V.L.; Maksimov, N.G. Electrochemical degradation of Mordant Blue 13 azo dye using boron-doped diamond and dimensionally stable anodes: Influence of experimental parameters and water matrix. Environ. Sci. Pollut. R 2018, 25, 30425-30440. [CrossRef] [PubMed]

24. Okochi, M.; Lim, T.-K.; Nakamura, N.; Matsunaga, T. Electrochemical disinfection of drinking water using an activated-carbon-fiber reactor capable of monitoring its microbial fouling. Appl. Microbiol. Biot. 1997, 47, 18-22. [CrossRef]

25. Cheryan, M. Ultrafiltration and Microfiltration Handbook; CRC Press: Boca Raton, FL, USA, 1998.

26. Guo, L.; Ding, K.; Rockne, K.; Duran, M.; Chaplin, B.P. Bacteria inactivation at a sub-stoichiometric titanium dioxide reactive electrochemical membrane. J. Hazard. Mater. 2016, 319, 137-146. [CrossRef] [PubMed]

27. McCartney, M. Waterlogged? Brit. Med. J. 2011, 343. [CrossRef] [PubMed]

28. Liang, S.; Lin, H.; Habteselassie, M.; Huang, Q. Electrochemical inactivation of bacteria with a titanium sub-oxide reactive membrane. Water Res. 2018, 145, 172-180. [CrossRef] [PubMed]

29. Petersen, R.C. Free-radicals and advanced chemistries involved in cell membrane organization influence oxygen diffusion and pathology treatment. Aims Biophys. 2017, 4, 240. [CrossRef] [PubMed]

30. Yang, B.; Deng, J.; Yu, G.; Deng, S.; Li, J.; Zhu, C.; Zhuo, Q.; Duan, H.; Guo, T. Effective degradation of carbamazepine using a novel electro-peroxone process involving simultaneous electrochemical generation of ozone and hydrogen peroxide. Electrochem. Commun. 2018, 86, 26-29. [CrossRef]

31. Xie, R.; Meng, X.; Sun, P.; Niu, J.; Jiang, W.; Bottomley, L.; Li, D.; Chen, Y.; Crittenden, J. Electrochemical oxidation of ofloxacin using a $\mathrm{TiO}_{2}$-based $\mathrm{SnO}_{2}-\mathrm{Sb} /$ polytetrafluoroethylene resin- $\mathrm{PbO}_{2}$ electrode: Reaction kinetics and mass transfer impact. Appl. Catal. B 2017, 203, 515-525. [CrossRef]

32. Bakheet, B.; Islam, M.A.; Beardall, J.; Zhang, X.; McCarthy, D. Effective electrochemical inactivation of Microcystis aeruginosa and degradation of microcystins via a novel solid polymer electrolyte sandwich. Chem. Eng. J. 2018, 350, 616-626. [CrossRef]

33. Brillas, E.; Martínez-Huitle, C.A. Decontamination of wastewaters containing synthetic organic dyes by electrochemical methods. An updated review. Appl. Catal. B 2015, 166, 603-643. [CrossRef]

(C) 2019 by the authors. Licensee MDPI, Basel, Switzerland. This article is an open access article distributed under the terms and conditions of the Creative Commons Attribution (CC BY) license (http://creativecommons.org/licenses/by/4.0/). 